\title{
Adrenergic regulation of immune cell function and inflammation
}

\author{
Drashya Sharma $^{1} \cdot$ J. David Farrar ${ }^{1}$ \\ Received: 5 November 2020 / Accepted: 14 November 2020 / Published online: 20 November 2020 \\ (C) Springer-Verlag GmbH Germany, part of Springer Nature 2020
}

\begin{abstract}
The sympathetic nervous system integrates the functions of multiple organ systems by regulating their autonomic physiological activities. The immune system is regulated both locally and systemically by the neurotransmitters epinephrine and norepinephrine secreted by the adrenal gland and local sympathetic neurons. Immune cells respond by activation of adrenergic receptors, primarily the $\beta 2$-adrenergic receptor, which signal through heterotrimeric G-proteins. Depending upon the cell type, adrenergic signaling regulates a variety of functions in immune cells ranging from cellular migration to cytokine secretion. Furthermore, due to the diurnal oscillation of systemic norepinephrine levels, various immune functions follow a circadian rhythmic pattern. This review will highlight recent advances in our understanding of how the sympathetic nervous system regulates both innate and adaptive immune functions and how this regulation is linked to circadian rhythms.
\end{abstract}

\section{Systemic pathways of adrenergic regulation}

The sympathetic nervous system controls a myriad of biological processes, and, perhaps, the most well-studied regulators of this system are the neurotransmitters epinephrine (E) and norepinephrine (NE). They both bind and signal through the adrenergic class of G-protein-coupled receptors whose members are differentially expressed on various cells and tissues throughout the body. The receptors are divided into $\alpha$ - and $\beta$ family members, and their selective expression, coupled to unique G- $\alpha$ downstream second messengers, conveys unique signals to individual cell types. In this way, E and NE can simultaneously regulate distinct functions in many organ systems.

The immune system is intimately connected to the sympathetic nervous system [1]. Early studies demonstrated that both primary and secondary lymphoid tissues are innervated by post-ganglionic sympathetic nerve fibers that predominantly secrete NE as their primary neurotransmitter [2-12]. Immune cells come in direct contact with the dendrites of these neurons. Both innate and adaptive immune cells express

This article is a contribution to the special issue on: Neuro-immune Interactions - Guest Editor: David Farrar

J. David Farrar

david.farrar@utsouthwestern.edu

1 Department of Immunology, UT Southwestern Medical Center, Dallas, TX, USA adrenergic receptors, primarily the $\beta 2$-adrenergic receptor (ADRB2), enabling them to directly respond to the sympathetic nervous system [12].

Sympathetic nerves secrete NE in response to pathogenic organisms (reviewed in [12]). While signaling through pattern recognition receptors (PRRs) promotes inflammatory cytokine secretion from antigen-presenting cells, neurons themselves express various Toll-like receptors (TLRs), enabling them to respond directly to certain pathogen-associated molecular patterns (PAMPs) [13-19]. Both viral and bacterial infections elicit bursts of NE secretion from sympathetic neurons, and PAMPs such as lipopolysaccharide (LPS) drive NE release within seconds upon exposure. This intimate relationship between sympathetic neurons and immune cells creates a direct conversation between the two organ systems and establishes reciprocal pathways of regulation. In general, adrenergic signaling is immunosuppressive in nature and has been reviewed extensively. In this review, we will provide an update on novel and recent research into adrenergic regulatory pathways that impact immune function and homeostasis.

\section{Control of innate responses-antigen presentation, innate sensing, and cytokine secretion}

Inflammation is a delicately balanced process that utilizes cytotoxic elements to sterilize tissues, and collateral damage is a necessary but dangerous component. Without checks and 
balances, immune cells proceed without limits to destroy cells and tissues within infected areas, and various immune suppressors are in place to limit this destruction. Immune tolerance and suppression collectively limit the magnitude of inflammation, which is necessary for overall survival. Along with well-characterized mechanisms such as central and peripheral tolerance, checkpoint inhibition, and cytokinemediated suppression, adrenergic signaling is a potent suppressive pathway that limits both inflammatory cytokine signaling and priming of $\mathrm{T}$ cells. In addition to the known effects of glucocorticoids, early studies demonstrated that both $\mathrm{E}$ and synthetic $\beta 2$-agonists could dramatically suppress TNF- $\alpha$ secretion in macrophages responding to LPS [20].

We and others have demonstrated that ADRB2 signaling suppresses inflammatory cytokine secretion from both macrophages and dendritic cells in response to LPS [21, 22]. In our study, we found that this pathway was not exclusive to a TLR4 agonist, as $\beta$-agonists, including NE, suppressed virtually all TLR pathways encompassing both intracellular and extracellular sensors [23]. While some components of this pathway may be directly blocking NF-kB activation [24], IL-10, highly induced by NE, acts in an autocrine fashion to block TNF- $\alpha$ and other inflammatory cytokines. Consequently, deletion of the ADRB2 in macrophages and dendritic cells leads to a severe loss of IL-10 secretion and elevated systemic TNF- $\alpha$ levels in vivo in response to LPS. In fact, ADRB2 loss was found to be lethal in LPS-induced sepsis models, highlighting its critical role in protection against harmful endotoxemia $[21,23]$. A single exogenous treatment of IL-10 can rescue ADRB2-deficient mice from lethal LPS toxicity, and antibody blockade of the IL-10R reverses the protective effect of NE. Consequently, IL-10 induction may represent the primary downstream target of the antiinflammatory properties of $\mathrm{E}$ and $\mathrm{NE}$.

Clinically, E, NE, and other vasopressors are administered as front-line therapeutics in sepsis-associated hypotension with the primary goal of restoring blood pressure $[25,26]$. In septic patients, there is a pivotal shift in cytokine profiles shortly after $\mathrm{E}$ administration highlighted by a marked reduction in serum TNF- $\alpha$ coupled with a rise in IL-10 [27-29]. Given the important role of IL-10 in suppressing both local and systemic inflammatory processes, the induction of this immunosuppressive cytokine by $\mathrm{E}$ and $\mathrm{NE}$ underscores the critical role of the sympathetic nervous system in mitigating the damaging effects of inflammation. This comes at a cost, however, since the very processes that eliminate infection are inhibited by IL-10, potentially allowing pathogen replication and spread. Nonetheless, there is clear evidence that adrenergic stimulation provides dual protection in sepsis by restoring blood pressure and by suppressing inflammatory cytokines.

In addition to suppressing inflammatory cytokines, ADRB2 signaling also modulates various other innate cell activities, which have downstream effects on both $\mathrm{B}$ and $\mathrm{T}$ cell responses. For example, $\beta 2$-agonists suppress the proTh1-inducing cytokine IL-12 in dendritic cells while increasing IL-10 secretion, thus blocking Th1 responses [30-32]. This may be due, in part, to the effects of NE on driving alternative M2 macrophage development, which is characterized by an anti-inflammatory phenotype dominated by IL-10 rather than TNF- $\alpha$ and other inflammatory cytokines [21]. Indeed, these suppressive effects are seen in the innate response of NK cells to virus infection, as loss of ADRB2 enhances IFN- $\gamma$ and lytic activity of NK cells in response to MCMV [33].

Antigen presentation to $\mathrm{T}$ cells is a hallmark activity of innate cells including DCs, macrophages, monocytes, and B cells. Early studies indicated that NE could suppress IFN- $\gamma$ induced MHC-II expression on astrocytes [34, 35] and other tissue resident antigen-presenting cells, such as langerhans cells [36]. Thus, $\beta 2$-agonists can promote tolerance by limiting antigen presentation, and recent studies have demonstrated that ADRB2 signaling limits the magnitude of $\mathrm{CD}^{+} \mathrm{T}$ cell priming by suppressing cross-presentation in dendritic cells [37]. Interestingly, the opposite has been observed in B cells, where adrenergic signaling increases the ability of $\mathrm{B}$ cells to present antigen and activate $\mathrm{CD} 4^{+} \mathrm{T}$ cells [38], through the co-stimulatory molecules B71/B72 [39]. B cell help is enhanced in this situation resulting in elevated IgG1 secretion overall [38, 40].

Although expression of $\alpha$-ARs may be low on immune cells, there is some evidence that the $\alpha 1$-adrenergic (ADRA1) may act to amplify cytokine secretion in innate cells, placing $\alpha$ and $\beta$ receptors in opposing roles in regulating cytokine-mediated inflammation [41]. Whether the ADRA1 is acting directly to drive cytokine secretion from innate cells is unclear; however, blockade of the $\alpha 1$-AR suppresses cytokine-mediated inflammation in the context of bacterial infections. Indeed, it has been suggested that blocking the $\alpha 1$-adrenergic receptor may be a viable therapeutic intervention to suppress the cytokine storm observed in severe COVID-19 patients [42].

\section{Regulation of $\mathrm{T}$ cell effector functions}

Cytokines have a profound impact on $\mathrm{T}$ cell function and their development into distinct subsets of effector and memory cell populations. For example, IL-12 secreted by DCs drives Th1 and $\mathrm{CD} 8^{+} \mathrm{CTL}$ development in response to both bacterial and viral infections [43, 44]. Other cytokines, such as IL-2, IL-4, IL-10 and IFN- $\alpha / \beta$ promote alternative pathways of Th2, Treg, and memory cell development [45-52]. Early studies demonstrated that $\mathrm{CD}^{+}{ }^{+} \mathrm{T}$ cells express the ADRB2 [53, 54], and more recent studies identified differential expression on subsets of effector and memory $\mathrm{CD} 8^{+} \mathrm{T}$ cells $[55,56]$. $\mathrm{CD}^{+} \mathrm{T}$ cells regulate multiple aspects of effector and memory 
responses through selective cytokine secretion [57], and both naive and in vitro polarized Th1 cells preferentially express ADRB2 with limited expression on Th2 cells [53, 54]. Stimulation of polarized Th1 cells suppressed IFN- $\gamma$ secretion while having little effect on IL-4 or IL-5 secretion from Th2 cells. Furthermore, NE stimulation can tip the balance toward Th17 development due to effects on dendritic cell priming [32]. In contrast, while the ADRB2 is more highly expressed on effector and memory effector $\mathrm{CD} 8^{+} \mathrm{T}$ cells, NE and $\beta$ agonists effectively suppress IFN- $\gamma$ and TNF- $\alpha$ secretion from all $\mathrm{CD}^{+}$subsets, and this suppression was specific for TCR-induced functions as stimulation with IL-12 + IL-18 was unaffected by NE to suppress IFN- $\gamma$ secretion [56]. In addition, ADRB2 signaling effectively suppresses cytolytic activity in $\mathrm{CD}^{+}$CTLs. In contrast, ADRB2 signaling has been shown to enhance NK cell expansion and effector function in vivo in response to virus infection [58]. It is unclear yet how the adrenergic pathway influences long-term memory $\mathrm{T}$ cell development. Thus, the overall activities of NE on T cells seem to fall in line with it immunosuppressive effects on innate cells described above.

While adrenergic signaling modulates activation-induced cytokine expression, conversely, cytokine responsiveness modulates expression of the ADRB2 on T cells, creating a reciprocal feedback loop during innate priming of $\mathrm{T}$ cells during infection [59]. For example, IL-2 activation enhances ADRB2 expression in T cells [59] while IL-12 increases its expression on both $\mathrm{CD} 8^{+} \mathrm{T}$ cells and NK cells $[56,58]$, making them more sensitive to the effects of NE stimulation. Given the immunosuppressive effects of NE, increasing the intrinsic expression of ADRB2 may provide the cells with an additional layer of modulation that can prevent over activation and limit collateral damage during effector responses. Indeed, chemical sympathectomy with 6-hydroxydopamine potently accelerates the $\mathrm{CD}^{+} \mathrm{T}$ cell response to influenza [60], indicating a clear role for $\mathrm{NE}$ in suppressing the overall magnitude of the CTL response. In some cases, ADRB2 signaling may promote $\mathrm{Th} 2$ responses and suppress Th1 development in the absence of overt infection. In HSV DNA vaccine-challenged mice, treatment with the $\beta 2$-specific agonist salbutamol elicited Th2 driven immune response indicated by high levels of HSV specific IgG1 antibodies compared with IgG2a, providing protective immunity to mucosal challenge with live virus [61].

In addition to suppressing overt $\mathrm{T}$ cell-mediated inflammation, ADRB2 activation can potentially promote $\mathrm{T}$ cell tolerance by driving Treg development [62-64]. ADRB2 signaling promotes Treg devolvement by inducing FoxP3 expression in $\mathrm{CD}^{+} \mathrm{T}$ cells [63]. This pathway may be accentuated in the context of tolerance to self-antigens presented by resting DCs, as NE can promote IL-10 secretion in these APCs [23, 65]. Curiously, however, FoxP3 induction was independent of IL10R activation [63], and other studies have shown a direct induction of Treg activity by ADRB2 activation on Treg cells [66]. Regardless of the precise mechanism, these studies highlight the role of adrenergic signaling in suppressing effector $\mathrm{T}$ cell responses in both $\mathrm{CD} 4^{+}$and $\mathrm{CD} 8^{+} \mathrm{T}$ cells and potentially driving inducible Treg development in peripheral $\mathrm{CD}^{+} \mathrm{T}$ cells to self-antigens.

\section{Inflammation in the context of chronic disease}

Stimulation of the sympathetic neurons that innervate secondary lymphoid organs has been shown to suppress inflammation in a variety of chronic diseases. For example, pioneering work from Tracey and colleagues has shown that electrical stimulation of the vagus nerve significantly suppresses inflammation by blocking secretion of inflammatory cytokines both locally and systemically (reviewed in $[67,68]$ ). The complex mechanisms underlying this suppression involve acetylcholine and the $\alpha 7$ - nicotinic receptor [69]. Under certain conditions, release of $\mathrm{NE}$ by the splenic nerve stimulates $\mathrm{T}$ cells, promoting their secretion of acetylcholine which can suppress innate cell cytokine secretion [70, 71]. This pathway is powerful and has been harnessed to treat a variety of chronic inflammatory diseases. The mechanism of vagus nerve suppression relies on acetylcholine production from immune cells since secondary lymphoid organs are only innervated by sympathetic nerves that secrete NE rather than acetylcholine. However, it is quite likely that NE acts directly on macrophages and DCs to suppress inflammatory cytokine secretion, particularly in response to PAMPs [72, 73].

In the context of autoimmunity, studies have focused on the role of NE in the central nervous system (CNS) in mouse models of experimental autoimmune encephalomyelitis EAE [74]. Early studies found a direct correlation between elevated $\mathrm{NE}$ and reduction in severity of CNS inflammation [75]. Depletion of central adrenergic nerves lowered NE levels and significantly increased the severity of EAE as compared with controls. Moreover, treatment with L-DOPA, a NE precursor with non-tricyclic NE selective reuptake inhibitor atomoxetine, increased CNS NE levels and reduced EAE symptoms. Furthermore, the downstream transcription factor NR4A1 was shown to be critical in NE-mediated suppression of neuroinflammation through effects on macrophage recruitment and activation [76]. Recently, a direct role for ADRB2 on immune cells was found to be critical for the antiinflammatory properties of NE in EAE [77]. In humans, there is some evidence that expression of both dopaminergic and adrenergic receptors on lymphocytes may be considered as a contributing biomarker in the progression of MS [78].

Allergic asthma is another well-studied chronic inflammatory disease, perhaps in which the role of NE and $\beta 2$-agonists is most notable in restoring lung function and promoting 
airway clearance $[79,80]$. Allergic asthma is generally classified as a "type 2 " response, being heralded by innate lymphocyte-2 (ILC2) and their induction of allergen-specific Th2 cells leading to IgE secretion in responding B cells (reviewed in $[81,82]$ ). Th2 cells were the original hallmark cellular phenotype that characterized allergic conditions, and multiple signaling pathways converge to drive their development, including IL-4, IL-33, and TSLP [83]. Recently, CD8 ${ }^{+}$ Tc2 cells have also been shown to play a distinct role in asthma pathogenesis [84]. Type 2 responses are guided by innate cytokines that drive the development of $\mathrm{Th} 2, \mathrm{Tc} 2$, and other inflammatory phenotypes such as Th17 cells. ILC2 cells, in particular, have been shown to play a key role in early priming events, acting as a potent source of Th2-inducing cytokines such as IL-4. Recently, Moriyama et al. [85] found that the ADRB2 played a significant role in ILC2 suppression, and deletion of the ADRB2 led to exacerbated type 2 responses in gut mucosal tissues. Perhaps, the most potent counter regulatory cytokine found to inhibit this pathway is the antiviral cytokine IFN- $\alpha / \beta[51,86]$. IFN- $\alpha / \beta$ suppresses the development and cytokine secretion potential of $\mathrm{CD}^{+} \mathrm{Th} 2$ cells $[50$, 87]; it can also reverse the Th2 phenotype of pre-committed cells, even from allergic subjects [88]. This suppression is accomplished by blocking the induced expression of the key Th2 transcription factor GATA3 $[50,89]$. This is particularly important in the context of upper respiratory viral infections which drive the secretion of IFN- $\alpha / \beta[90,91]$ as specific Toll agonists have been proposed as therapeutic agents to reverse the allergic phenotype. Yet, viral infections are a particular nuisance in allergic diseases, causing severe exacerbations of allergic asthma. This is a significant conundrum with the use of $\beta$-agonists, since recent studies have found that both $\operatorname{IgE}$ stimulation and NE can suppress virus-induced IFN- $\alpha / \beta$ secretion from dendritic cells [92-95]. Nonetheless, while $\beta$ agonists had very little effect on IL-4 secretion from Th2 cells in vitro [54], ADRB2 activation can prevent Th2-mediated inflammation with respect to allergic stimulation [96]. This places the use of $\beta$-agonists in a very precarious situation when treating allergic airway diseases impacted by respiratory viruses. The stimulation of the adrenergic pathway indeed restores lung function and may temporarily suppress acute Th2 cytokine secretion in vivo, yet it also suppresses IFN- $\alpha /$ $\beta$, which is key to reversing the Th2 state and blocking viral replication [86].

\section{Regulation of trafficking and circadian involvement}

Over the last 10 years, there have significant advances in the area of "chrono-immunology" and the role circadian rhythms play in immune function [97-99]. Circadian rhythms evolved in virtually all life forms in order to regulate biological processes that cycle with the needs of the organism as a function of light/dark cycles. In higher organisms, light signals are converted to biological oscillations of a set of core transcription factors that regulate a myriad of processes throughout the body, and immune cells are no exception to this. Light entrainment regulates expression of the core transcription factor Bmal1/2 within the suprachiasmatic nucleus ( $\mathrm{SCN}$ ) subregion of the hypothalamus [100]. As night falls, Bmal is extinguished by the action of the cryptochrome proteins Per and Cry. This oscillation regulates the expression of genes with the SCN to release neurotransmitters that entrain cells throughout the body. One of these external entrainment pathways is regulated by the sympathetic nervous system, and the secretion of NE is a major component to that systemic entrainment process. NE levels typically rise in response to light entrainment and fall at night.

Perhaps, the most well-documented aspect of circadian control of immune function is in the area of immune cell trafficking through lymphoid tissues [97, 101]. Nakai et al. $[102,103]$ found that lymphocyte recirculation through secondary lymphoid tissues followed a diurnal circadian pattern. Their retention and release was regulated by interactions with chemokine receptors and required the expression of ADRB2. Further treatment with $\beta$-agonists could alter their migration. In addition to trafficking, innate sensing is also impacted by circadian rhythms. Recent studies found that TLR9 is directly controlled by CLOCK, and diurnal oscillations in TLR9 regulated both the innate secretion of pro-inflammatory cytokines and the resulting adaptive response [104]. Whether this effect was regulated by adrenergic signaling was not explored. In humans, during sleep, low levels of sympathetic agonists, such as NE and prostaglandin E2, allow T cells to express $\beta 2$-integrins on their cells surface. This expression is normally suppressed by $\mathrm{G} \alpha$-receptor activation during wakefulness when the levels of these neurotransmitters are high [105]. Increased expression of integrins allows for differential recirculation of cells within lymphoid tissues.

In addition to trafficking, circadian rhythms also have the potential to influence an overt immune response in $\mathrm{T}$ cells. Indeed, $\mathrm{T}$ cells display a periodic oscillation of core circadian factors [106]. Interestingly, recent studies in $\mathrm{CD}^{+} \mathrm{T}$ cells found that the CLOCK gene was dispensable for primary effector responses to infection, although there was observed reduction in IL-2 responsiveness [107]. However, the case is quite different for $\mathrm{CD} 8^{+} \mathrm{T}$ cells. Here, loss of the primary oscillator Bmall in $\mathrm{CD}^{+} \mathrm{T}$ cells significantly altered their development into primary effector cells in response to virus infection [108]. Whether the ADRB2 is responsible for the entrainment of these cells is still an open question. Nonetheless, it is clear that immunity is controlled, in part by circadian oscillations, and identifying specific mechanisms of this regulation could open new avenues of therapeutic intervention. Significant questions remain in this area such as 
the role of the ADRB2 in the entrainment of immune cells, the requirement of rhythmic oscillations in effector and memory responses, and whether the time of day of infection influences the outcome of vaccines and immunotherapy.

The gut microbiome has come into focus recently as a key regulator of mucosal immune homeostasis, and perturbations in the microbiome lead to significant inflammatory conditions (reviewed in [109]). Like all organisms, the microbiome operates under the constraints of circadian rhythms and releases a variety of metabolites in a diurnal rhythmic fashion $[109,110]$. Recent studies have demonstrated that products from the microbiome can directly regulate inflammatory responses [111-113]. Thus, the microbiome establishes an important circadian rhythmic control of the local immune community at barrier interfaces.

\section{Conclusion}

The sympathetic nervous system plays a major role in controlling the biological processes including immune system, mediated via neuromodulators such as epinephrine and nor epinephrine. This neuroimmune communication is enabled by the adrenergic receptors, among which ADRB2 as a pivotal player is differentially expressed on innate and adaptive immune cells. To keep in check the necessary evil "inflammation," neurosignaling through ADRB2 limits the release of inflammatory cytokines from macrophages and dendritic cells, along with activation of $\mathrm{T}$ cells. As revealed by our previous studies, IL10 is a critical target downstream of $\mathrm{E}$ and NE to limit inflammation. The suppression of inflammation in varied chronic diseases is also exhibited by NE, which has been utilized for treatment of diseases such as allergic asthma where NE and $\beta 2$ agonists play major roles in restoring normal health conditions. Even the autoimmune diseases such as EAE in mouse have correlated the NE levels with decrease in CNS inflammation, underscoring the role of ADRB2 signaling in suppressing inflammation. Through sympathetic regulation, circadian rhythms also contribute to the timing and magnitude of specific functions of immune system. Recirculation of immune cells through lymphoid tissues and circulation has been well studied and demonstrated in context of circadian regulation. Much remains to be uncovered, and further revelations could open new avenues for the identification and development of prophylactic and therapeutic targets with improved clinical outcomes.

Funding This study is supported by funding from the NIH NIAID R21 AI143248.

\section{References}

1. Lorton D, Bellinger DL (2015) Molecular mechanisms underlying beta-adrenergic receptor-mediated cross-talk between sympathetic neurons and immune cells. Int J Mol Sci 16(3):5635-5665. https:// doi.org/10.3390/ijms16035635

2. Felten DL, Overhage JM, Felten SY, Schmedtje JF (1981) Noradrenergic sympathetic innervation of lymphoid tissue in the rabbit appendix: further evidence for a link between the nervous and immune systems. Brain Res Bull 7(5):595-612

3. Williams JM, Felten DL (1981) Sympathetic innervation of murine thymus and spleen: a comparative histofluorescence study. Anat Rec 199(4):531-542. https://doi.org/10.1002/ar. 1091990409

4. Williams JM, Peterson RG, Shea PA, Schmedtje JF, Bauer DC, Felten DL (1981) Sympathetic innervation of murine thymus and spleen: evidence for a functional link between the nervous and immune systems. Brain Res Bull 6(1):83-94

5. Felten DL, Felten SY, Carlson SL, Olschowka JA, Livnat S (1985) Noradrenergic and peptidergic innervation of lymphoid tissue. J Immunol 135(2 Suppl):755s-765s

6. Felten DL, Ackerman KD, Wiegand SJ, Felten SY (1987) Noradrenergic sympathetic innervation of the spleen: I. Nerve fibers associate with lymphocytes and macrophages in specific compartments of the splenic white pulp. J Neurosci Res 18(1): 28-36 118-121

7. Kendall MD, al-Shawaf AA (1991) Innervation of the rat thymus gland. Brain Behav Immun 5(1):9-28

8. Kendall MD, Atkinson BA, Munoz FJ, de la Riva C, Clarke AG, von Gaudecker B (1994) The noradrenergic innervation of the rat thymus during pregnancy and in the post partum period. J Anat 185(Pt 3):617-625

9. Reilly FD, McCuskey PA, Miller ML, McCuskey RS, Meineke HA (1979) Innervation of the periarteriolar lymphatic sheath of the spleen. Tissue Cell 11(1):121-126

10. Villaro AC, Sesma MP, Vazquez JJ (1987) Innervation of mouse lymph nodes: nerve endings on muscular vessels and reticular cells. Am J Anat 179(2):175-185. https://doi.org/10.1002/aja. 1001790210

11. Panuncio AL, De La Pena S, Gualco G, Reissenweber N (1999) Adrenergic innervation in reactive human lymph nodes. J Anat 194(Pt 1):143-146

12. Nance DM, Sanders VM (2007) Autonomic innervation and regulation of the immune system (1987-2007). Brain Behav Immun 21(6):736-745. https://doi.org/10.1016/j.bbi.2007.03.008

13. Burgueno JF, Barba A, Eyre E, Romero C, Neunlist M, Fernandez E (2016) TLR2 and TLR9 modulate enteric nervous system inflammatory responses to lipopolysaccharide. J Neuroinflammation 13(1):187. https://doi.org/10.1186/s12974016-0653-0

14. Zhao M, Zhou A, Xu L, Zhang X (2014) The role of TLR4mediated PTEN/PI3K/AKT/NF-kappaB signaling pathway in neuroinflammation in hippocampal neurons. Neuroscience 269: 93-101. https://doi.org/10.1016/j.neuroscience.2014.03.039

15. Helley MP, Abate W, Jackson SK, Bennett JH, Thompson SW (2015) The expression of Toll-like receptor 4, 7 and co-receptors in neurochemical sub-populations of rat trigeminal ganglion sensory neurons. Neuroscience 310:686-698. https://doi.org/10. 1016/j.neuroscience.2015.09.069

16. Liu HY, Hong YF, Huang CM, Chen CY, Huang TN, Hsueh YP (2013) TLR7 negatively regulates dendrite outgrowth through the Myd88-c-Fos-IL-6 pathway. J Neurosci 33(28):11479-11493. https://doi.org/10.1523/JNEUROSCI.5566-12.2013

17. Kaul D, Habbel P, Derkow K, Kruger C, Franzoni E, Wulczyn FG, Bereswill S, Nitsch R, Schott E, Veh R, Naumann T, Lehnardt 
S (2012) Expression of Toll-like receptors in the developing brain. PLoS One 7(5):e37767. https://doi.org/10.1371/journal.pone. 0037767

18. Peltier DC, Simms A, Farmer JR, Miller DJ (2010) Human neuronal cells possess functional cytoplasmic and TLR-mediated innate immune pathways influenced by phosphatidylinositol-3 kinase signaling. J Immunol 184(12):7010-7021. https://doi.org/10. 4049/jimmunol.0904133

19. Ma Y, Haynes RL, Sidman RL, Vartanian T (2007) TLR8: an innate immune receptor in brain, neurons and axons. Cell Cycle 6(23):2859-2868. https://doi.org/10.4161/cc.6.23.5018

20. Spengler RN, Chensue SW, Giacherio DA, Blenk N, Kunkel SL (1994) Endogenous norepinephrine regulates tumor necrosis factor-alpha production from macrophages in vitro. J Immunol 152(6):3024-3031

21. Grailer JJ, Haggadone MD, Sarma JV, Zetoune FS, Ward PA (2014) Induction of M2 regulatory macrophages through the beta2-adrenergic receptor with protection during endotoxemia and acute lung injury. J Innate Immun 6(5):607-618. https://doi. org/10.1159/000358524

22. Donnelly LE, Tudhope SJ, Fenwick PS, Barnes PJ (2010) Effects of formoterol and salmeterol on cytokine release from monocytederived macrophages. Eur Respir J 36(1):178-186. https://doi.org/ 10.1183/09031936.00158008

23. Agac D, Estrada LD, Maples R, Hooper LV, Farrar JD (2018) The beta2-adrenergic receptor controls inflammation by driving rapid IL-10 secretion. Brain Behav Immun 74:176-185. https://doi.org/ 10.1016/j.bbi.2018.09.004

24. Kizaki T, Shirato K, Sakurai T, Ogasawara JE, Oh-ishi S, Matsuoka T, Izawa T, Imaizumi K, Haga S, Ohno H (2009) Beta2-adrenergic receptor regulate Toll-like receptor 4-induced late-phase NF-kappaB activation. Mol Immunol 46(6):11951203. https://doi.org/10.1016/j.molimm.2008.11.005

25. Li Y, Li H, Zhang D (2020) Timing of norepinephrine initiation in patients with septic shock: a systematic review and meta-analysis. Crit Care 24(1):488. https://doi.org/10.1186/s13054-020-03204-x

26. Pollard S, Edwin SB, Alaniz C (2015) Vasopressor and inotropic management of patients with septic shock. P T 40(7):438-450

27. Stolk RF, van der Poll T, Angus DC, van der Hoeven JG, Pickkers P, Kox M (2016) Potentially inadvertent immunomodulation: norepinephrine use in sepsis. Am J Respir Crit Care Med 194(5):550 558. https://doi.org/10.1164/rccm.201604-0862CP

28. Stolk RF, van der Pasch E, Naumann F, Schouwstra J, Bressers S, van Herwaarden AE, Gerretsen J, Schambergen R, Ruth MM, van der Hoeven JG, van Leeuwen H, Pickkers P, Kox M (2020) Norepinephrine dysregulates the immune response and compromises host defense during sepsis. Am J Respir Crit Care Med 202(6):830-842. https://doi.org/10.1164/rccm.202002-0339OC

29. van der Poll T, Coyle SM, Barbosa K, Braxton CC, Lowry SF (1996) Epinephrine inhibits tumor necrosis factor-alpha and potentiates interleukin 10 production during human endotoxemia. J Clin Invest 97(3):713-719. https://doi.org/10.1172/JCI118469

30. Kim B-J, Jones HP (2010) Epinephrine-primed murine bone marrow-derived dendritic cells facilitate production of IL-17A and IL-4 but not IFN- $\gamma$ by CD4+ T cells. Brain Behav Immun 24(7):1126-1136. https://doi.org/10.1016/j.bbi.2010.05.003

31. Mizuno K, Takahashi HK, Iwagaki H, Katsuno G, Kamurul HA, Ohtani S, Mori S, Yoshino T, Nishibori M, Tanaka N (2005) Beta2-adrenergic receptor stimulation inhibits LPS-induced IL18 and IL-12 production in monocytes. Immunol Lett 101(2): 168-172. https://doi.org/10.1016/j.imlet.2005.05.008

32. Takenaka MC, Araujo LP, Maricato JT, Nascimento VM, Guereschi MG, Rezende RM, Quintana FJ, Basso AS (2016) Norepinephrine controls effector $\mathrm{T}$ cell differentiation through beta2-adrenergic receptor-mediated inhibition of NF-kappaB and AP-1 in dendritic cells. J Immunol 196(2):637-644. https:// doi.org/10.4049/jimmunol.1501206

33. Wieduwild E, Girard-Madoux MJ, Quatrini L, Laprie C, Chasson L, Rossignol R, Bernat C, Guia S, Ugolini S (2020) beta2adrenergic signals downregulate the innate immune response and reduce host resistance to viral infection. J Exp Med 214(4): e20190554. https://doi.org/10.1084/jem.20190554

34. Frohman EM, Vayuvegula B, Gupta S, van den Noort S (1988) Norepinephrine inhibits gamma-interferon-induced major histocompatibility class II (Ia) antigen expression on cultured astrocytes via beta-2-adrenergic signal transduction mechanisms. Proc Natl Acad Sci U S A 85(4):1292-1296. https://doi.org/10. 1073/pnas.85.4.1292

35. Neumann H, Boucraut J, Hahnel C, Misgeld T, Wekerle H (1996) Neuronal control of MHC class II inducibility in rat astrocytes and microglia. Eur J Neurosci 8(12):2582-2590. https://doi.org/10. 1111/j.1460-9568.1996.tb01552.x

36. Seiffert K, Hosoi J, Torii H, Ozawa H, Ding W, Campton K, Wagner JA, Granstein RD (2002) Catecholamines inhibit the antigen-presenting capability of epidermal Langerhans cells. J Immunol 168(12):6128-6135. https://doi.org/10.4049/jimmunol. 168.12.6128

37. Herve J, Dubreil L, Tardif V, Terme M, Pogu S, Anegon I, Rozec B, Gauthier C, Bach JM, Blancou P (2013) beta2-Adrenoreceptor agonist inhibits antigen cross-presentation by dendritic cells. $\mathrm{J}$ Immunol 190(7):3163-3171. https://doi.org/10.4049/jimmunol. 1201391

38. Podojil JR, Sanders VM (2005) CD86 and beta2-adrenergic receptor stimulation regulate B-cell activity cooperatively. Trends Immunol 26(4):180-185. https://doi.org/10.1016/j.it.2005.02.005

39. Kohm AP, Mozaffarian A, Sanders VM (2002) B cell receptorand beta 2-adrenergic receptor-induced regulation of B7-2 (CD86) expression in B cells. J Immunol 168(12):6314-6322

40. Podojil JR, Sanders VM (2003) Selective regulation of mature IgG1 transcription by CD86 and beta 2-adrenergic receptor stimulation. J Immunol 170(10):5143-5151

41. Staedtke V, Bai RY, Kim K, Darvas M, Davila ML, Riggins GJ, Rothman PB, Papadopoulos N, Kinzler KW, Vogelstein B, Zhou S (2018) Disruption of a self-amplifying catecholamine loop reduces cytokine release syndrome. Nature 564(7735):273-277. https://doi.org/10.1038/s41586-018-0774-y

42. Konig MF, Powell M, Staedtke V, Bai RY, Thomas DL, Fischer N, Huq S, Khalafallah AM, Koenecke A, Xiong R, Mensh B, Papadopoulos N, Kinzler KW, Vogelstein B, Vogelstein JT, Athey S, Zhou S, Bettegowda C (2020) Preventing cytokine storm syndrome in COVID-19 using alpha-1 adrenergic receptor antagonists. J Clin Invest 130(7):3345-3347. https://doi.org/10.1172/ JCI139642

43. Hsieh CS, Macatonia SE, Tripp CS, Wolf SF, O'Garra A, Murphy KM (1993) Development of TH1 CD4+ T cells through IL-12 produced by Listeria-induced macrophages. Science 260(5107): 547-549

44. Pearce EL, Shen H (2007) Generation of CD8 T cell memory is regulated by IL-12. J Immunol 179(4):2074-2081

45. Pipkin ME, Sacks JA, Cruz-Guilloty F, Lichtenheld MG, Bevan MJ, Rao A (2010) Interleukin-2 and inflammation induce distinct transcriptional programs that promote the differentiation of effector cytolytic T cells. Immunity 32(1):79-90. https://doi.org/10. 1016/j.immuni.2009.11.012

46. Farrar JD, Asnagli H, Murphy KM (2002) T helper subset development: roles of instruction, selection, and transcription. J Clin Invest 109(4):431-435

47. Palomares O, Martin-Fontecha M, Lauener R, Traidl-Hoffmann C, Cavkaytar O, Akdis M, Akdis CA (2014) Regulatory T cells and immune regulation of allergic diseases: roles of IL-10 and 
TGF-beta. Genes Immun 15(8):511-520. https://doi.org/10.1038/ gene. 2014.45

48. Hsieh CS, Heimberger AB, Gold JS, O'Garra A, Murphy KM (1992) Differential regulation of T helper phenotype development by interleukins 4 and 10 in an alpha beta T-cell-receptor transgenic system. Proc Natl Acad Sci U S A 89(13):6065-6069

49. Ramos HJ, Davis AM, Cole AG, Schatzle JD, Forman J, Farrar JD (2009) Reciprocal responsiveness to interleukin-12 and interferonalpha specifies human CD8+ effector versus central memory Tcell fates. Blood 113(22):5516-5525. https://doi.org/10.1182/ blood-2008-11-188458

50. Huber JP, Ramos HJ, Gill MA, Farrar JD (2010) Cutting edge: Type I IFN reverses human Th2 commitment and stability by suppressing GATA3. J Immunol 185(2):813-817. https://doi. org/10.4049/jimmunol.1000469

51. Huber JP, Farrar JD (2011) Regulation of effector and memory Tcell functions by type I interferon. Immunology 132(4):466-474. https://doi.org/10.1111/j.1365-2567.2011.03412.x

52. Fujio K, Okamura T, Yamamoto K (2010) The family of IL-10secreting CD4+ T cells. Adv Immunol 105:99-130. https://doi. org/10.1016/S0065-2776(10)05004-2

53. Ramer-Quinn DS, Baker RA, Sanders VM (1997) Activated T helper 1 and $\mathrm{T}$ helper 2 cells differentially express the beta-2adrenergic receptor: a mechanism for selective modulation of $\mathrm{T}$ helper 1 cell cytokine production. J Immunol 159(10):4857-4867

54. Sanders VM, Baker RA, Ramer-Quinn DS, Kasprowicz DJ, Fuchs BA, Street NE (1997) Differential expression of the beta2-adrenergic receptor by Th1 and Th2 clones: implications for cytokine production and B cell help. J Immunol 158(9): 4200-4210

55. Slota C, Shi A, Chen G, Bevans M, Weng NP (2015) Norepinephrine preferentially modulates memory CD8 T cell function inducing inflammatory cytokine production and reducing proliferation in response to activation. Brain Behav Immun 46:168-179. https://doi.org/10.1016/j.bbi.2015.01.015

56. Estrada LD, Ağaç D, Farrar JD (2016) Sympathetic neural signaling via the $\beta 2$-adrenergic receptor suppresses T-cell receptor-mediated human and mouse CD8(+) T-cell effector function. Eur J Immunol 46(8):1948-1958. https://doi.org/10.1002/eji. 201646395

57. Davis AM, Hagan KA, Matthews LA, Bajwa G, Gill MA, Gale M Jr, Farrar JD (2008) Blockade of virus infection by human CD4+ T cells via a cytokine relay network. J Immunol 180(10):69236932

58. Diaz-Salazar C, Bou-Puerto R, Mujal AM, Lau CM, von Hoesslin M, Zehn D, Sun JC (2020) Cell-intrinsic adrenergic signaling controls the adaptive NK cell response to viral infection. J Exp Med 214(4):e20190554. https://doi.org/10.1084/jem.20190549

59. Wahle M, Stachetzki U, Krause A, Pierer M, Hantzschel H, Baerwald CG (2001) Regulation of beta2-adrenergic receptors on CD4 and CD8 positive lymphocytes by cytokines in vitro. Cytokine 16(6):205-209. https://doi.org/10.1006/cyto.2001.0965

60. Grebe KM, Hickman HD, Irvine KR, Takeda K, Bennink JR, Yewdell JW (2009) Sympathetic nervous system control of antiinfluenza CD8+ T cell responses. Proc Natl Acad Sci U S A 106(13):5300-5305. https://doi.org/10.1073/pnas.0808851106

61. Kim SB, Han YW, Rahman MM, Kim SJ, Yoo DJ, Kang SH, Kim K, Eo SK (2009) Modulation of protective immunity against herpes simplex virus via mucosal genetic co-transfer of DNA vaccine with beta2-adrenergic agonist. Exp Mol Med 41(11):812823. https://doi.org/10.3858/emm.2009.41.11.087

62. Dugger KJ, Chrisman T, Sayner SL, Chastain P, Watson K, Estes $\mathrm{R}$ (2018) Beta-2 adrenergic receptors increase TREG cell suppression in an OVA-induced allergic asthma mouse model when mice are moderate aerobically exercised. BMC Immunol 19(1):9. https://doi.org/10.1186/s12865-018-0244-1
63. Nijhuis LE, Olivier BJ, Dhawan S, Hilbers FW, Boon L, Wolkers MC, Samsom JN, de Jonge WJ (2014) Adrenergic beta2 receptor activation stimulates anti-inflammatory properties of dendritic cells in vitro. PLoS One 9(1):e85086. https://doi.org/10.1371/ journal.pone. 0085086

64. Wang J, Yu L, Jiang C, Fu X, Liu X, Wang M, Ou C, Cui X, Zhou C, Wang J (2015) Cerebral ischemia increases bone marrow $\mathrm{CD} 4+\mathrm{CD} 25+\mathrm{FoxP} 3+$ regulatory $\mathrm{T}$ cells in mice via signals from sympathetic nervous system. Brain Behav Immun 43:172-183. https://doi.org/10.1016/j.bbi.2014.07.022

65. Eijkelkamp N, Cobelens PM, Sanders VM, Heijnen CJ, Kavelaars A (2004) Tissue specific effects of the beta 2-adrenergic agonist salbutamol on LPS-induced IFN-gamma, IL-10 and TGF-beta responses in vivo. J Neuroimmunol 150(1-2):3-9. https://doi.org/ 10.1016/j.jneuroim.2004.01.001

66. Vida G, Pena G, Kanashiro A, Thompson-Bonilla Mdel R, Palange D, Deitch EA, Ulloa L (2011) beta2-Adrenoreceptors of regulatory lymphocytes are essential for vagal neuromodulation of the innate immune system. FASEB J 25(12):4476-4485. https://doi.org/10.1096/fj.11-191007

67. Chavan SS, Pavlov VA, Tracey KJ (2017) Mechanisms and Therapeutic Relevance of Neuro-immune Communication. Immunity 46(6):927-942. https://doi.org/10.1016/j.immuni. 2017.06.008

68. Pavlov VA, Tracey KJ (2017) Neural regulation of immunity: molecular mechanisms and clinical translation. Nat Neurosci 20(2):156-166. https://doi.org/10.1038/nn.4477

69. Bonaz B, Sinniger V, Pellissier S (2016) Anti-inflammatory properties of the vagus nerve: potential therapeutic implications of vagus nerve stimulation. J Physiol 594(20):5781-5790. https:// doi.org/10.1113/JP271539

70. Rosas-Ballina M, Olofsson PS, Ochani M, Valdes-Ferrer SI, Levine YA, Reardon C, Tusche MW, Pavlov VA, Andersson U, Chavan S, Mak TW, Tracey KJ (2011) Acetylcholinesynthesizing $\mathrm{T}$ cells relay neural signals in a vagus nerve circuit. Science 334(6052):98-101. https://doi.org/10.1126/science. 1209985

71. Olofsson PS, Katz DA, Rosas-Ballina M, Levine YA, Ochani M, Valdes-Ferrer SI, Pavlov VA, Tracey KJ, Chavan SS (2012) alpha7 nicotinic acetylcholine receptor (alpha7nAChR) expression in bone marrow-derived non- $\mathrm{T}$ cells is required for the inflammatory reflex. Mol Med 18:539-543. https://doi.org/10.2119/ molmed.2011.00405

72. Takenaka MC, Guereschi MG, Basso AS (2017) Neuroimmune interactions: dendritic cell modulation by the sympathetic nervous system. Semin Immunopathol 39(2):165-176. https://doi.org/10. 1007/s00281-016-0590-0

73. Guyot M, Simon T, Panzolini C, Ceppo F, Daoudlarian D, Murris E, Macia E, Abelanet S, Sridhar A, Vervoordeldonk MJ, Glaichenhaus N, Blancou P (2019) Apical splenic nerve electrical stimulation discloses an anti-inflammatory pathway relying on adrenergic and nicotinic receptors in myeloid cells. Brain Behav Immun 80:238-246. https://doi.org/10.1016/j.bbi.2019.03.015

74. Haerter K, Vroon A, Kavelaars A, Heijnen CJ, Limmroth V, Espinosa E, Schedlowski M, Elsenbruch S (2004) In vitro adrenergic modulation of cellular immune functions in experimental autoimmune encephalomyelitis. J Neuroimmunol 146(1-2):126132. https://doi.org/10.1016/j.jneuroim.2003.10.051

75. Simonini MV, Polak PE, Sharp A, McGuire S, Galea E, Feinstein DL (2010) Increasing CNS noradrenaline reduces EAE severity. J Neuroimmune Pharmacol 5(2):252-259. https://doi.org/10.1007/ s11481-009-9182-2

76. Shaked I, Hanna RN, Shaked H, Chodaczek G, Nowyhed HN, Tweet G, Tacke R, Basat AB, Mikulski Z, Togher S, Miller J, Blatchley A, Salek-Ardakani S, Darvas M, Kaikkonen MU, Thomas GD, Lai-Wing-Sun S, Rezk A, Bar-Or A, Glass CK, 
Bandukwala H, Hedrick CC (2015) Transcription factor Nr4a1 couples sympathetic and inflammatory cues in CNS-recruited macrophages to limit neuroinflammation. Nat Immunol 16(12): 1228-1234. https://doi.org/10.1038/ni.3321

77. Araujo LP, Maricato JT, Guereschi MG, Takenaka MC, Nascimento VM, de Melo FM, Quintana FJ, Brum PC, Basso AS (2019) The sympathetic nervous system mitigates CNS autoimmunity via beta2-adrenergic receptor signaling in immune cells. Cell Rep 28(12):3120-3130 e3125. https://doi.org/10. 1016/j.celrep.2019.08.042

78. Cosentino M, Zaffaroni M, Legnaro M, Bombelli R, Schembri L, Baroncini D, Bianchi A, Clerici R, Guidotti M, Banfi P, Bono G, Marino F (2016) Dopaminergic receptors and adrenoceptors in circulating lymphocytes as putative biomarkers for the early onset and progression of multiple sclerosis. J Neuroimmunol 298:8289. https://doi.org/10.1016/j.jneuroim.2016.07.008

79. Albertson TE, Chenoweth JA, Pearson SJ, Murin S (2020) The pharmacological management of asthma-chronic obstructive pulmonary disease overlap syndrome (ACOS). Expert Opin Pharmacother 21(2):213-231. https://doi.org/10.1080/14656566. 2019.1701656

80. Antonioli L, Blandizzi C, Pacher P, Hasko G (2019) The purinergic system as a pharmacological target for the treatment of immune-mediated inflammatory diseases. Pharmacol Rev 71(3):345-382. https://doi.org/10.1124/pr.117.014878

81. Akdis CA, Arkwright PD, Bruggen MC, Busse W, Gadina M, Guttman-Yassky E, Kabashima K, Mitamura Y, Vian L, Wu J, Palomares $\mathrm{O}$ (2020) Type 2 immunity in the skin and lungs. Allergy 75(7):1582-1605. https://doi.org/10.1111/all.14318

82. Huang C, Li F, Wang J, Tian Z (2019) Innate-like lymphocytes and innate lymphoid cells in asthma. Clin Rev Allergy Immunol. https://doi.org/10.1007/s12016-019-08773-6

83. Lambrecht BN, Hammad H, Fahy JV (2019) The cytokines of asthma. Immunity 50(4):975-991. https://doi.org/10.1016/j. immuni.2019.03.018

84. Hinks TSC, Hoyle RD, Gelfand EW (2019) CD8(+) Tc2 cells: underappreciated contributors to severe asthma. Eur Respir Rev 28(154):190092. https://doi.org/10.1183/16000617.0092-2019

85. Moriyama S, Brestoff JR, Flamar AL, Moeller JB, Klose CSN, Rankin LC, Yudanin NA, Monticelli LA, Putzel GG, Rodewald HR, Artis D (2018) beta2-adrenergic receptor-mediated negative regulation of group 2 innate lymphoid cell responses. Science 359(6379):1056-1061. https://doi.org/10.1126/science.aan4829

86. Gonzales-van Horn SR, Farrar JD (2015) Interferon at the crossroads of allergy and viral infections. J Leukoc Biol 98(2):185194. https://doi.org/10.1189/jlb.3RU0315-099R

87. Gonzales-van Horn SR, Estrada LD, van Oers NS, Farrar JD (2016) STAT4-mediated transcriptional repression of the IL5 gene in human memory Th2 cells. Eur J Immunol 46(6):1504 1510. https://doi.org/10.1002/eji.201546050

88. Chen F, Rowe RK, Gill MA, Farrar JD (2019) Type I interferon suppresses memory Th2 cell cytokine secretion from allergic subjects. Allergy. 75:695-698. https://doi.org/10.1111/all.14056

89. Huber JP, Gonzales-van Horn SR, Roybal KT, Gill MA, Farrar JD (2014) IFN-alpha suppresses GATA3 transcription from a distal exon and promotes $\mathrm{H} 3 \mathrm{~K} 27$ trimethylation of the CNS-1 enhancer in human Th2 cells. J Immunol 192(12):5687-5694. https://doi. org/10.4049/jimmunol.1301908

90. Gill MA (2012) The role of dendritic cells in asthma. J Allergy Clin Immunol 129(4):889-901. https://doi.org/10.1016/j.jaci. 2012.02.028

91. Rowe RK, Gill MA (2015) Asthma: the interplay between viral infections and allergic diseases. Immunol Allergy Clin North Am 35(1):115-127. https://doi.org/10.1016/j.iac.2014.09.012

92. Gill MA, Bajwa G, George TA, Dong CC, Dougherty II, Jiang N, Gan VN, Gruchalla RS (2010) Counterregulation between the
FcepsilonRI pathway and antiviral responses in human plasmacytoid dendritic cells. J Immunol 184(11):5999-6006. https://doi.org/10.4049/jimmunol.0901194

93. Bajwa G, DeBerardinis RJ, Shao B, Hall B, Farrar JD, Gill MA (2016) Cutting edge: critical role of glycolysis in human plasmacytoid dendritic cell antiviral responses. J Immunol 196(5):2004-2009. https://doi.org/10.4049/jimmunol.1501557

94. Gill MA, Liu AH, Calatroni A, Krouse RZ, Shao B, Schiltz A, Gern JE, Togias A, Busse WW (2017) Enhanced plasmacytoid dendritic cell antiviral responses after omalizumab. J Allergy Clin Immunol. 141:1735-1743.e9. https://doi.org/10.1016/j.jaci.2017. 07.035

95. Rowe RK, Pyle DM, Farrar JD, Gill MA (2020) IgE-mediated regulation of IL-10 and type I IFN enhances rhinovirus-induced Th2 differentiation by primary human monocytes. Eur J Immunol 50(10):1550-1559. https://doi.org/10.1002/eji.201948396

96. Kato G, Takahashi K, Tashiro H, Kurata K, Shirai H, Kimura S, Hayashi S (2014) beta2 adrenergic agonist attenuates house dust mite-induced allergic airway inflammation through dendritic cells. BMC Immunol 15:39. https://doi.org/10.1186/s12865-014-0039$\mathrm{y}$

97. Scheiermann C, Kunisaki Y, Frenette PS (2013) Circadian control of the immune system. Nat Rev Immunol 13(3):190-198. https:// doi.org/10.1038/nri3386

98. Cermakian N, Lange T, Golombek D, Sarkar D, Nakao A, Shibata S, Mazzoccoli G (2013) Crosstalk between the circadian clock circuitry and the immune system. Chronobiol Int 30(7):870-888. https://doi.org/10.3109/07420528.2013.782315

99. Geiger SS, Fagundes CT, Siegel RM (2015) Chrono-immunology: progress and challenges in understanding links between the circadian and immune systems. Immunology 146(3):349-358. https://doi.org/10.1111/imm.12525

100. Cermakian N, Sassone-Corsi P (2002) Environmental stimulus perception and control of circadian clocks. Curr Opin Neurobiol 12(4):359-365. https://doi.org/10.1016/s0959-4388(02)00347-1

101. Labrecque N, Cermakian N (2015) Circadian clocks in the immune system. J Biol Rhythms 30(4):277-290. https://doi.org/10. 1177/0748730415577723

102. Nakai A, Hayano Y, Furuta F, Noda M, Suzuki K (2014) Control of lymphocyte egress from lymph nodes through beta2-adrenergic receptors. J Exp Med 211(13):2583-2598. https://doi.org/10. 1084/jem.20141132

103. Suzuki K, Hayano Y, Nakai A, Furuta F, Noda M (2016) Adrenergic control of the adaptive immune response by diurnal lymphocyte recirculation through lymph nodes. J Exp Med 213(12):2567-2574. https://doi.org/10.1084/jem.20160723

104. Silver AC, Arjona A, Walker WE, Fikrig E (2012) The circadian clock controls toll-like receptor 9-mediated innate and adaptive immunity. Immunity 36(2):251-261. https://doi.org/10.1016/j. immuni.2011.12.017

105. Dimitrov S, Lange T, Gouttefangeas C, Jensen ATR, Szczepanski M, Lehnnolz J, Soekadar S, Rammensee HG, Born J, Besedovsky L (2019) Galphas-coupled receptor signaling and sleep regulate integrin activation of human antigen-specific T cells. J Exp Med 216(3):517-526. https://doi.org/10.1084/jem.20181169

106. Bollinger T, Leutz A, Leliavski A, Skrum L, Kovac J, Bonacina L, Benedict C, Lange T, Westermann J, Oster H, Solbach W (2011) Circadian clocks in mouse and human CD4+ T cells. PLoS One 6(12):e29801. https://doi.org/10.1371/journal.pone.0029801

107. Hemmers S, Rudensky AY (2015) The cell-intrinsic circadian clock is dispensable for lymphocyte differentiation and function. Cell Rep 11(9):1339-1349. https://doi.org/10.1016/j.celrep.2015. 04.058

108. Nobis CC, Dubeau Laramee G, Kervezee L, Maurice De Sousa D, Labrecque N, Cermakian N (2019) The circadian clock of CD8 T cells modulates their early response to vaccination and the 
rhythmicity of related signaling pathways. Proc Natl Acad Sci U S A 116(40):20077-20086. https://doi.org/10.1073/pnas. 1905080116

109. Brooks JF 2nd, Hooper LV (2020) Interactions among microbes, the immune system, and the circadian clock. Semin Immunopathol. https://doi.org/10.1007/s00281-020-00820-1

110. Butler TD, Gibbs JE (2020) Circadian host-microbiome interactions in immunity. Front Immunol 11:1783. https://doi.org/10. 3389/fimmu.2020.01783

111. Rosser EC, Piper CJM, Matei DE, Blair PA, Rendeiro AF, Orford M, Alber DG, Krausgruber T, Catalan D, Klein N, Manson JJ, Drozdov I, Bock C, Wedderburn LR, Eaton S, Mauri C (2020) Microbiota-derived metabolites suppress arthritis by amplifying aryl-hydrocarbon receptor activation in regulatory B cells. Cell Metab 31(4):837-851 e810. https://doi.org/10.1016/j.cmet.2020. 03.003
112. Hang S, Paik D, Yao L, Kim E, Trinath J, Lu J, Ha S, Nelson BN, Kelly SP, Wu L, Zheng Y, Longman RS, Rastinejad F, Devlin AS, Krout MR, Fischbach MA, Littman DR, Huh JR (2019) Bile acid metabolites control TH17 and Treg cell differentiation. Nature 576(7785):143-148. https://doi.org/10.1038/s41586-019-1785-z

113. Campbell C, McKenney PT, Konstantinovsky D, Isaeva OI, Schizas M, Verter J, Mai C, Jin WB, Guo CJ, Violante S, Ramos RJ, Cross JR, Kadaveru K, Hambor J, Rudensky AY (2020) Bacterial metabolism of bile acids promotes generation of peripheral regulatory T cells. Nature 581(7809):475-479. https://doi.org/10.1038/s41586-020-2193-0

Publisher's note Springer Nature remains neutral with regard to jurisdictional claims in published maps and institutional affiliations. 